\title{
NOTES
}

\section{PUTTING LIFE INSURANCE BEYOND THE CLAIMS OF TRUSTEES IN BANKRUPTCY}

In addition to fulfilling its primary purpose of protecting the designated beneficiary upon the death of the insured, life insurance has become one of the best recognized forms of investment and self-compelled saving. ${ }^{\text {I }}$ Because of the latter characteristics, the cash surrender value of a policy on the life of the bankrupt insured frequently is a valuable asset of the estate. Debtors, as might be expected, have sought to avoid relinquishing to their creditors any part of their policies. It will be the object of this note to analyze both the extent to which this may be legitimately done and the attempts of unscrupulous debtors to use their life insurance policies as a means of avoiding the claims of creditors in bankruptcy.

\section{I}

The trustee gets rights only to that life insurance which comes within $\S 70(a)(3)$ or the proviso to $\S 70(a)(5) .^{2}$ The early cases ${ }^{3}$ held that life insurance, like any other species of property, came within the terms of the body of

$x$ Holmes, J. in Grigsby v. Russell, 222 U.S. I49 (IgrI).

${ }^{2}$ II U.S.C.A. \& Iro (1927). The provisions of the Bankruptcy Act applicable to determining the trustee's rights to life insurance policies are: "\$ 70 . Title to Property-(a) The trustee .... shall ... be vested by operation of law with the title of the bankrupt, as of the date he was adjudged a bankrupt except in so far as it is to property which is exempt, to all .... (3) powers which he might have exercised for his own benefit, but not those which he might have exercised for some other person .... (5) property which prior to the filing of the petition he could by any means have transferred or which might have been levied upon and sold under judicial process against him: Provided, that when any bankrupt shall have any insurance policy which has a cash surrender value payable to himself, his estate, or personal representatives, he may, within thirty days after the cash surrender value has been ascertained and stated to the trustee by the company issuing the same, pay or secure to the trustee the sum so ascertained and stated, and continue to hold, own, and carry such policy free from the claims of the creditors participating in the distribution of his estate under the bankruptcy proceedings, otherwise the policy shall pass to the trustee as assets. ...."

Where the dealings of the bankrupt with his life insurance are under state law fraudulent as to his creditors, those dealings may be set aside by the trustee just as he might avoid fraudulent conveyance of other property under $\& 70(\mathrm{a})(4)$ or under $\& 70(\mathrm{e})$, which empowers the trustee to "avoid any transfer by the bankrupt which any creditor of such bankrupt might have avoided." II U.S.C.A. § Iro(e) (I927). Kirkpatrick v. Johnson, 197 Fed. 235 (D.C. Pa. I912). The same result was reached under the Bankruptcy Act of 1867 . Barnes v. Vetterlein, I6 Fed. 218 (D.C. N.Y. 1882 ).

${ }^{3}$ In re Slingful, 106 Fed. I54 (D.C. Md. 1900 ); In re Welling, II 3 Fed. 189 (C.C.A. 7 th Ig02). 
$\S 70(a)(5)$ so that any insurance on the life of the bankrupt which, prior to the filing of the petition, the bankrupt could have transferred by any means would pass to the trustee; and the proviso was merely a qualification which permitted the bankrupt to redeem certain types of policies described therein. But the United States Supreme Court, in an endeavor to protect the beneficiaries, reversed these decisions and held that the sole source of the trustee's title to life insurance policies is the proviso and that the rest of $\S 70(a)(5)$ does not affect the trustee's rights. ${ }^{4}$ As the proviso has been construed, the trustee is never entitled to more than the cash surrender value of the policy.5 Where there is no cash surrender value at the time the petition in bankruptcy is filed, the trustee gets nothing-not even a part of the proceeds upon the subsequent death of the insured. ${ }^{6} \S 70$ (a) has been further construed not to give the trustee the title to the policy subject to the bankrupt's right of redemption but to invest him with a power to demand the cash surrender value. Unless the trustee exercises this power before the policy matures, the beneficiary's interest becomes indefeasible and the trustee acquires no interest whatsoever in the policy. ${ }^{7}$ Although the trustee pays premiums on the policy and the bankrupt fails to redeem ${ }^{8}$ it within the time specified by the proviso, upon the death of the insured, the beneficiaries

$4 \mathrm{~A}$ proviso sometimes embodies additional legislation although its usual function is to limit generalities and exclude from the scope of the statute that which would otherwise be within its terms. Burlingham v. Crouse, 228 U.S. 459 (Igr3).

5 Remington, Bankruptcy § I243 (r923).

6 Burlingham v. Crouse, 228 U.S. 459 (Igr3).

7 Eldredge v. Mutual Life Ins. Co., 2I 7 Mass. 444, ro5 N.E. 36I (I9I4) (suit against both the insurance company and beneficiary before the insurer had paid the beneficiary). Frederick v. Fidelity Mut. Life Ins. Co., 256 U.S. 395 (I921) has been regarded as standing for the same proposition. See 35 Harv. L. Rev. 80, 82 (I921); Vance, Insurance (2d ed. I930). This assumption finds no support in the express language of the Frederick case which was only determining the rights of the insurance company after the company had paid the beneficiary. See the decision at p. 398 .

${ }^{8}$ In order to prevent the policy from.being surrendered by the trustee, the bankrupt must pay the trustee the cash surrender value of the policy within thirty days. $\S 70(a)(5)$, supra note 2. This presents a problem of serious proportions since, by hypothesis, the bankruptcy proceedings leave the bankrupt without any substantial amount of money. If the insured is unable to borrow money from his friends, he should be able to arrange to borrow the cash surrender value from the insurer. Because the cash surrender and loan values of the policy are approximately the same (Vance, Insurance, 285 (2d ed. 1930)) whenever there is a cash surrender value there will be a loan value. It is possible, however, that if the insurance company knows of the petition in bankruptcy, it will refuse to lend money to the bankrupt, for after it has received actual notice of the proceedings it cannot safely pay money to the insured. See Frederick v. Fidelity Insurance Co., 256 U.S. 395 (I92I). The bankrupt should therefore arrange to have the insurer pay the money to the trustee directly. He should have no difficulty in securing the consent of both the trustee and the insurer to some such settlement for it is to the interest of the insurance company that the policy should not lapse and the interests of the bankrupt's creditors are not prejudiced if the insured retains the policy and they receive payment in some manner. Furthermore, $\S 7 \circ(\mathrm{a})(5)$ gives the bankrupt the option of paying or securing the cash surrender value to the trustee. 
obtain the entire proceeds less the cash surrender value as of the time the petition was filed.9

The express wording of the proviso to $\S 70(a)(5)$ gives the trustee the cash surrender value only when the beneficiary is the bankrupt or his estate..$^{\text {I0 }}$ A literal construction of the language would have made it possible to deprive the trustee of all his rights to the debtor's life insurance. The insured simply by making a third person the beneficiary and reserving to himself the right to change the beneficiary could prevent the trustee's acquiring any interest in the policy while, in reality, retaining full control over the cash value of the policy, a control which he could exercise to his own advantage after his discharge in bankruptcy. ${ }^{\text {II }}$ This type of evasion has been prevented by giving to the trustee the insured's power to change the beneficiary. The result is reached by virtue of $\$ 70$ (a)(3) which gives the trustee "the powers which the bankrupt might have exercised for his own benefit." ${ }_{12}$ Even in the absence of $\S 70(a)(3)$ the same conclusion would probably be reached to prevent fraud..$^{x_{3}}$

Where neither the right to change the beneficiary nor the right to get the cash surrender value is reserved by the insured, the third party beneficiary acquires an absolute vested interest in the insurance, ${ }^{14}$ and, in the absence of fraud, neither the cash surrender value during the life of the insured nor any part of the proceeds upon his death pass to the trustee because the vested interest of the beneficiary does not constitute an asset of the bankrupt estate, the insurance not being within the sole control of the insured. ${ }^{15}$ The making of such a policy and the payment of premiums by the bankrupt while solvent were valid gifts

9 Ehrhart v. New York Life Ins. Co., 45 F. (2d) 804 (D.C. Mll. I929). Query whether the trustee should not be repaid for his expenditure on the premiums.

so See $\$$ 7o(a), supra note 2.

sx Cohen v. Samuels, 245 U.S. 50 (Igr 7 ).

12 Cohen v. Samuels, ibid.; Malone v. Cohn, 236 Fed. 882 (C.C.A. $5^{\text {th }}$ rgr6). The trustee, however, would still be limited to recovering the cash surrender value.

${ }_{3}$ Cohen v. Samuels, supra note Ir, at p. 53. Cf. Dean v. Davis, 242 U.S. 438 (I9I7).

${ }^{14}$ "By saying that the beneficiary's right is 'vested' is meant that the beneficiary has a right to receive such sum as may become payable in accordance with the terms of the policy, coupled with an immunity from destruction of that right by any modification or cancellation of the policy by the agreement of the insured and insurer to which the beneficiary does not consent." Vance, The Beneficiary's Interest in a Life Insurance Policy, 3I Yale L. J. 343, 344 (1922). In determining whether the third party has an absolute and vested beneficial interest which cannot be reached by the trustee, two distinct questions must be answered: first, has the insured reserved to himself the right to change the beneficiary? Second, assuming that he has not, can he reach the cash surrender value without the consent of the beneficiary? If either question is answered affirmatively, the trustee can get the cash surrender value. "It may be conceded that in the standard policy both the right to change the beneficiary are options or privileges reserved to the insured, either one of which, if exercised, would clearly convert the policy into property in his hands." See $I n$ re Pinals, 38 F. (2d) II7, II9 (D.C. N.J. I93O).

${ }^{25}$ In re Fetterman, 243 Fed. 975 (D.C. Ohio I9I7); In re Grant, 21 F. (2d) 88 (D.C. Wis. I927); In re Cooper's Estate, 28 F. (2d) 438 (D.C. Md. I928). 
and not affected by the donor's subsequent bankruptcy. ${ }^{16}$ Accordingly, where a third person is an absolute beneficiary, he may, after the bankruptcy of the insured, get the cash surrender value from the insurer and give it to the insured free from the claims of the trustee. ${ }^{17}$ And if the insured should pay a creditor within the four months' period with money borrowed on the policy by the absolute beneficiary, he has not bestowed a voidable preference for there is no diminution of the bankrupt estate..$^{8}$

When the insured while insolvent changes the beneficiary of a policy that has a cash surrender value from his estate to a third person but reserves to himself the right to make further change of beneficiary, the trustee should get the cash surrender value as of the time of the filing of the petition by virtue of $\S 7 \circ(a)(3) .19$ However, if the insured also surrenders his right to change the beneficiary, the third person gets a vested interest which is not defeasible by the insured.20 Here $\$ 7 \mathrm{o}(\mathrm{a})(3)$ would be of no aid to the trustee because no power exists which the bankrupt could have exercised before the petition was filed. This should not leave the trustee without a remedy; on the theory of a fraudulent conveyance he should be able to recover the cash surrender value. ${ }^{2 x}$ The revision of the policy is, in effect, a gift of the cash surrender value by the insolvent, ${ }^{22}$ for, by surrendering his right to change the beneficiary, the insured

${ }^{16} \mathrm{~A}$ gift by a solvent debtor is not a fraudulent conveyance. Glenn, Fraudulent Conveyances $\$ 270$ (I93I).

"In re Fetterman, supra note ${ }^{15}$. It is a common practice to build up large insurance policies as a form of investment as well as for the purpose of protecting dependents. By the above method, the cash surrender value of such policies, in the event of bankruptcy, is available to the insured so long as no premiums were paid while he was insolvent. The insured must, of course, depend upon the cooperation of the beneficiary in "cashing" the policy and in giving him the proceeds; but this hazard is generally less than the ordinary hazards of business. The objection to this device is that the cash surrender value is usually less than the policy's reserve value (which is equal to the amount of premiums paid in less that sum set aside each year by the insurer to enable him to pay the face value of the policy on the death of the insured) because the insurance companies wish to discourage the surrendering of policies. Vance, Insurance 55 ( $2 \mathrm{~d}$ ed. $x 930$ ). This being true, the insured is paying more than the actual cost of insuring his life, so that while he is solvent he has less incentive to invest in insurance, which will be exempt in the event of bankruptcy, than in other things, which while not exempt will yield a higher return.

${ }^{8}$ Crosby v. Sproul, I7 F. (2d) 325 (D.C. Mass. 1927).

19 Since the insured still controls the policy by his having reserved the right to change the beneficiary, the case is within the doctrine of Cohen v. Samuels, supra note II.

so Supra note I4.

25 On this point, there is a paucity of bankruptcy cases. Cf. I6 Va. L. Rev. 27I, 276 (I930) which agrees that theoretically the change in the policy constitutes a fraudulent conveyance but contends that the law is the other way, citing In re Fetterman, 243 Fed. 975 (D.C. Ohio r9r 7); In re Steele, 98 Fed. 78 (D.C. Ia. I899); see McEwen v. N.Y. Life Ins. Co., 43 Calif. App. I33, I8 3 Pac. 373,376 (I9I9). However, these authorities are not in point.

$2 \mathrm{~A}$ gift by an insolvent debtor is a fraudulent conveyance. Glenn, Fraudulent Conveyances $\$ 270$ (1931). 
gave the third person an indefeasible interest in the policy at a time when it had a definite value to creditors. The same result should follow where the policy originally made a third person the beneficiary and the insured, while insolvent, surrenders his right to change the beneficiary and attempts thereby to give the third person a vested interest. Here again the giving up of the power to change the beneficiary constitutes a fraudulent transfer for it deprives the trustee of the opportunity both to exercise that power for the benefit of the creditors, and to make available to them the cash value. The same problem is raised where the insured, while insolvent, does not change the beneficiary but assigns the policy without consideration. Here the assignment has been considered to be a fraudulent conveyance. ${ }^{23}$

Where the policy has no cash surrender value at the time the petition in bankruptcy is filed, the subsequent death of the insured entitles the beneficiary to the entire proceeds clear of any claims of the trustee, even though the insured has always reserved the right to change the beneficiary. ${ }^{24}$ The same result should be reached where the insured's estate was the beneficiary, but while insolvent and when there was no cash surrender value, the insured made a third party an absolute beneficiary. The vesting of the indefeasible interest in the beneficiary is not a fraudulent conveyance because under generally accepted rules, creditors do not have any means of reaching such a policy, and because there is no value in the policy which would have gone to the trustee under the proviso to $\S 7 \circ(\mathrm{a})(5)$ if there had been no change in the beneficiary. Navassa Guano Co. v. Ellen Nixon Cockfield 25 raises the interesting question whether the fact that the appointment of an absolute beneficiary is made in anticipation of death changes a transfer otherwise valid into a fraudulent conveyance. These are the facts of the case: a creditor's bill was brought in the federal court to recover the full proceeds of a policy after the death of the insured who, while insolvent and in anticipation of imminent death, changed the beneficial interest from his estate to his brother. At the time of the change and before the death of the insured there was no cash surrender value. The new beneficiary contended that if the insured had died a bankrupt, the trustee would have failed to get the proceeds because the policy had no cash surrender value before the insured's death and that, by analogy, the same result should follow in a proceeding on a

${ }^{23}$ Kirkpatrick v. Johnson, I97 Fed. 235 (D.C. Pa. I9I2).

${ }^{24}$ Everett v. Judson, 228 U.S. 474 (Igr3); Burlingham v. Crouse, 228 U.S. 459 (Igr3). Contra, but decided before the United States Supreme Court decisions, In re Welling, I I3 Fed. I89 (C.C.A. 7 th I902); In re Slingluff, I06 Fed. I54 (D.C. Md. I900). These cases were based on the theory that $\$ 70(\mathrm{a})(5)$ permitted the bankrupt-insured to redeem only policies with cash surrender values, and that policies having no cash values passed to the trustee without being redeemable. See 35 Harv. L. Rev. 80 (I92I) supporting this interpretation. Where the policy has no cash surrender value at the time the petition is filed because the bankrupt, while insolvent, borrowed on it, the trustee may follow that sum into the hands of a donee and recover it as the subject of a fraudulent conveyance. Butler v. Rand, II F. Supp. 343 (D.C. N.Y. I935)

${ }^{25} 253$ Fed. 883 (C.C.A. $4^{\text {th }}$ IgI8). 
creditor's bill. The court ruled that the creditors were entitled to the proceeds on a fraudulent conveyance theory. Despite the fact that the state law was well settled that had the insured entertained ordinary expectations of life, the same act would not have constituted a fraudulent conveyance, the certainty of death at the time of the change of beneficiary gave the policy a definite value so that it could be the subject matter of a fraudulent conveyance. It is conceivable that the court might have reached the same result if the proceedings had been in bankruptcy. To do this the trustee would have to proceed under $\S 70(\mathrm{e})$ or $\S 70(a)(4)^{26}$ on a theory that under the state law there had been a fraudulent conveyance. The defense would have to rely on the many decisions ${ }^{27}$ construing the proviso to $\S 70(a)(5)$ as never giving the trustee more than the cash surrender value as of the time the petition was filed and would have to argue that this policy prevails over the express language of $\S 7 \circ(\mathrm{a})(4)$ and $\S 70(\mathrm{e})$. In this connection Morris v. Dodd ${ }^{28}$ is pertinent. There the insured, within one month of bankruptcy, made his wife the beneficiary in place of his estate. Upon the subsequent death of the insured, the trustee sought to recover the proceeds under $\S 7 \mathrm{o}(\mathrm{e})$. It was held that the trustee acquired no rights in a policy having no cash value before death. The trustee did not raise the point that the change of the beneficiary was made in contemplation of death. Consequently, while the case is not directly opposed to the Navassa case, it is significant because the court refused to inquire into the state law to determine the validity of the transfer. Instead, it argued vigorously that the policy of the proviso to $\S 70(a)(5)$ was to restrict the bankrupt in the use of his insurance only to the extent of the cash surrender value.

\section{II}

The right of a trustee to get the cash surrender value under $\S$ 7o(a)(5) is limited by state exemption statutes ${ }^{29}$ which are generally construed so liberally

${ }^{26}$ Supra note 2. See Hays v. Harris, 78 F. (2d) 66, 72 (C.C.A. 8th r935) for suggestion that, on a proper showing, the Navassa case might apply in bankruptcy. Because a petition in bankruptcy cannot be filed after the death of the debtor (see In re Hicks, Io7 Fed. 9ro (D.C. Vt. I9OI)) the above situation could only arise where the petition was filed before his death. Should it make any difference whether the change in beneficiary was made before or after the petition in bankruptcy was filed? The time of the change, it would appear, is immaterial; the determining fact is whether the insured became conscious of imminent death arose before or after the petition. If before, then any transfer is like a conveyance of a policy that has a cash surrender value- except that in the supposititious case, the amount of the fraudulent transfer would be the full amount of the proceeds.

${ }^{27}$ Ehrhart v. New York Life Ins. Co., supra note 9; Everett v. Judson, supra note 24. "As we have construed the statute $(\S 70(a)(5))$, its purpose was to vest the surrender value in the trustee for the benefit of the creditors, and not otherwise to limit the bankrupt in dealing with his policy." Burlingham v. Crouse, 228 U.S. at 473 (1913).

${ }^{28}$ IIo Ga. 606, 36 S.E. 83 (I900).

${ }^{29}$ Holden v. Stratten, I98 U.S. 202 (I9O5) is the leading case holding that under $\S 6$ and the introductory clause in $\S 70(a)(5)$, supra note 2 , state statutes exempting policies on the life of the insured should be given full effect in determining the trustee's rights. 
that in many cases $\S 70(a)(5)$ has been impotent to protect creditors. ${ }^{30}$ These statutes usually protect members of the insured's family ${ }^{3 \mathrm{x}}$ although some include any third persons. ${ }^{32}$ Assuming that the premiums were paid by the bankrupt while solvent ${ }^{33}$ and that the beneficiary is within the designated class, all statutes provide that all or a part of the proceeds are exempt from the claims of creditors upon the death of the insured bankrupt, 34 although under $\$ 70(a)(5)$ the trustee would have been entitled to the cash surrender value as of the date the petition in bankruptcy was filed. The fact that in the usual case the beneficiaries are dependent on the deceased would seem to be sufficient justification for the liberal exemption. But there is a sharp split of authority as to whether the cash value of the policy is exempt also during the life of the bankrupt. The statutes themselves are usually open to either construction, and whether they are to be construed as exempting the cash surrender value only after the death of the bankrupt or also during his life depends upon whether the court favors the creditors or the beneficiary. A splendid example of this conflict is found in Tennessee, the federal court in that state having decided both ways in recent years. In Igog it was said, "Whatever may have been the intention of these statutes, they were clearly not designed as a shield to protect the husband himself from his creditors and to enable him, under the guise of a contingent protection for his family, to make investments for his own benefit free from the claims of his creditors." ${ }^{35}$ In 1925 , in a case ${ }^{36}$ involving precisely the same stat-

${ }^{30}$ See In re Horwitz, 3 F. Supp. I6, I8 (D.C. N.Y. I933). It has been contended that the state exemption statutes should be liberally construed in favor of the beneficiary "in order to advance the humane purpose of preserving to the unfortunate or improvident debtor or his family the means of obtaining a livelihood and prevent them from becoming a charge on the public." Hickman v. Hanover, 33 F. (2d) 873 (C.C.A. $4^{\text {th }}$ 'r929).

${ }^{35}$ Brown v. Home Life Ins. Co., 3 F. (2d) 66r (D.C. Okla. r925); In re Stansell, 8 F. (2d) 363 (D.C. Tenn. r925); In re Grant, 2 r F. (2d) 88 (D.C. Wis. r927); In re Bendall, 28 F. (2d) 999 (D.C. N.D. I928); Hickman v. Hanover, 33 F. (2d) 873 (C.C.A. 4 th I929) (Md. stat.); Pearsall v. Bloodworth, 149 N.C. 628 , 140 S.E. 303 (1927); see In re Hammells, 5 F. (2d) 879, 880 (D.C. Ariz. 1925).

32 Murphy v. Casey, I5I Minn. 480, I84 N.W. 783 (I921); Mason’s Minn. Stat. 1927 § 3387; Cahill's Consol. N.Y. Laws (r930) c. $30, \S 55$ a, infra note 39 .

33 Where a third person is an absolute beneficiary and the insured has paid the premiums while insolvent, the trustee under $\S$ 7o(e) gets the same rights to the policy as do the creditors under the state law. 3 Remington, Bankruptcy \& I264 (r923).

34 See cases cited in notes 35 and 36 , infra, for total exemptions; Hickman v. Hanover, $33 \mathrm{~F}$. (2d) 873 (C.C.A. $4^{\text {th }}$ I929) (Md. stat. exempting up to $\$ 500.00$ ); Dreyfus v. Barton, 98 Miss. 758,54 So. 254 (IgII) (proceeds exempt up to $\$ 3000.00$ ).

35 In re Moore, 773 Fed. 679 (D.C. Tenn. x909). In accord, holding that the cash surrender value is not exempt from the trustee under the state statute during the life of the bankrupt, although the proceeds are exempt if the bankrupt is dead. In re Grant, 2r F. (2d) 88 (D.C. Wis. 1927) (the Wisconsin statute was subsequently construed contra by the state court in Cannon v. Lincoln Ins. Co., 208 Wis. 452, 243 N.W. 320 (I932)); Morgan v. McCaffrey, 286 Fed. 922 (C.C.A. 5th 1923); In re Samuels, 254 Fed. 775 (C.C.A. $2 d$ I918) decided before $\S 55$ A N.Y. Ins. Law was enacted, infra note 39.

${ }^{36}$ In re Stansell, 8 F. (2d) 363 (D.C. Tenn. I925). In accord, holding the entire cash surrender value exempt, although the debtor is alive, under state statutes which could just as well 
ute and situation, the court reversed itself and held that the cash value was exempt during the bankrupt's life. It said, "To sustain the principle laid down in our former decision would be, to a certain extent, to limit the benefits of life insurance to the solvent and to deprive the insured of his protection at the very time he needs it most, namely, when involved in financial difficulties." The effect of this later decision is to permit the bankrupt, after his discharge, to have the cash value for his own use. ${ }^{37}$ Query whether this does not violate the purpose of the Bankruptcy Act in that it not only gives a debtor a new start in life discharged of his liabilities but also gives him valuable assets. ${ }^{38}$ The effect of the later decision is to distinguish between money in the debtor's bank account at the time the petition in bankruptcy is filed and the same amount if invested in insurance which can readily be turned into cash by the bankrupt. $\S 70(a)(5)$ reaches a desirable compromise between the interests of the creditors and the beneficiaries by giving to the former the cash value of the insurance and protecting the latter by giving them the policy. If the state statutes are clear, then, of course, they must be enforced; but where they are ambiguous, they should not be construed so as to give the insured a windfall in the form of the cash surrender value. ${ }^{39}$

have been construed to apply only upon death of the insured. Cannon v. Lincoln Ins. Co., 208 Wis. 452, 243 N.W. 320 (1932); In re Young, 208 Fed. 373 (D.C. Ohio I9r2); In re Fetterman, 243 Fed. 975 (D.C. Ohio I917).

In some states where the courts had construed the exemption statute to apply only upon the death of the insured, the legislatures revised the statute so as to exempt the cash surrender value during the insured's life. In re Lang, 2o F. (2d) 236 (D.C. Pa. I927).

37 After the petition is filed, the bankrupt may make himself the beneficiary, or the beneficiary may borrow on the policy and give the proceeds to the bankrupt. The insured is thus indirectly protected as an incident of the general desire of the courts to protect the beneficiary. See In re Young, 208 Fed. 373, 378 (D.C. Ohio I9r2). The fact that the bankrupt after the petition is filed actually uses the cash surrender value rather than the beneficiary, does not affect the decisions. In re Vaughn, 2 F. Supp. 385 (D.C. Fla. I932); Cf. \& 55A N.Y. Stat. infra, note 39 .

${ }^{38}$ See Louisville Joint Stock Land Bank v. Radford, 295 U.S. 555, 582 (I935). It must be admitted, however, that the inevitable result of exemption statutes is to give the bankrupt assets. But where the exemption statutes do not clearly protect the beneficiary during the life of the insured, there should be no departure from the general objective of the Bankruptcy.Act.

39 But the weight of authority does not recognize any evil in giving effect to exemption statutes during the bankrupt's life. Supra note 36 . Recent legislation has encouraged this result. $\S 55 \mathrm{~A}$ of the N.Y. Ins. Law expressly applies to policies in which the insured has reserved the right to change the beneficiary; "If a policy of insurance . . . . is effected by any person on his own life or on another life, in favor of a person other than himself, or except in cases of transfer with intent to defraud creditors, if a policy of life insurance is assigned or in any way made payable to any such person, the lawful beneficiary or assignee thereof, other than the insured or the person so effecting such insurance . . . . shall be entitled to its proceeds and avails against the creditors and representatives of the insured .... whether or not the right to change the beneficiary is reserved or permitted, . . ." Cahill's Consol. N.Y. Laws (I930) c. $30, \S 55 \mathrm{~A}$. $\$ 55 \mathrm{~A}$ thus avoids the effect of In re Samuels, 254 Fed. 775 (C.C.A. $2 \mathrm{~d}$ 
The New York legislature has sought to achieve a compromise on this point. $\S 55$ (a) of the New York Insurance Law attempts both to protect the beneficiary and to preclude the insured bankrupt from using the cash surrender value for his personal advantage..$^{\circ}$ This sum is held exempt from the trustee when a third party is the beneficiary, ${ }^{4 x}$ but if the bankrupt is the beneficiary, or upon proof that he has changed the policy so as to get the cash value for his own use, ${ }^{42}$ that amount as of the date the petition was filed becomes administered as assets of the estate of the bankrupt. As a practical matter, the law is easily evaded. Since the beneficiary is permitted to cash in the policy before ${ }^{43}$ or after ${ }^{44}$ the petition in bankruptcy is filed, there is nothing to prevent his giving the proceeds to the insured. But the insured must be careful not to get the cash value in his own name from the insurer, for in that event the trustee may claim the proceeds. ${ }^{45}$ Therefore, the statute does make the cooperation of the beneficiary necessary, but in most cases this will not be an insuperable difficulty.

Igr8) which construed an older New York statute as not applicable during the life of the insured because of the absence of an express provision concerning the right to change the beneficiary. In contrast to the tendency for a liberal construction, Ehrhart v. New York Life Ins. Co., 45 F. (2d) 804 (D.C. Ill. I929) is interesting. An Illinois statute exempting insurance where the wife procures it on the life of her husband for her own benefit, had been so interpreted in state decisions that where the husband himself procured the insurance on his life for the benefit of his wife, but did not reserve the right to change the beneficiary, he was treated as the agent of his wife and the policy was within the statutory exemption. In the Ehrhart case, however, the federal court held that where the insured reserved the right to change the beneficiary, the policy which the husband secured for the benefit of his wife did not come within the statute even though the bankrupt had died after the petition, in spite of the fact that there was no danger of the insured's using the proceeds for himself. See also, In re Weisman, ro F. Supp. 312 (D.C. N.Y. 1934).

${ }^{40}$ Cahill's Consol. N.Y. Laws (r930) c. $30, \S 55 \mathrm{a}$; In re Messinger, 29 F. (2d) I58 (C.C.A. 2d 1928); In re Horwitz, 3 F. Supp. I6 (D.C. N.Y. I933); In re Beach, 8 F. Supp. 910 (D.C. Mass. 1934), placing a similar construction on a Massachusetts statute.

${ }^{4}$ Schwartz v. Holzman, 69 F. (2d) 8I4 (C.C.A. 2d I934).

43 See Schwartz v. Holzman, ibid.; Butler v. Rand, II F. Supp. 344 (D.C. N.Y. 1935).

43 Schwartz v. Holzman, supra note $4 \mathrm{r}$.

44 In re Messinger, supra note 40.

45 Butler v. Rand, II F. Supp. 343 (D.C. N.Y. I935), in which the insured borrowed $\$ 5,000$ on his policy and bought shares of stock for, and in the name of, his wife, who was the beneficiary under the policy. When the insured was adjudged bankrupt, his trustee in bankruptcy sought to set aside the transfer. It was held that the stock was not exempt within $\$ 55 \mathrm{a}$ of the N.Y. Ins. Law. Cf. Schwartz v. Holzman, supra note $4 \mathrm{I}$, where the insured prior to bankruptcy borrowed on the policy, received a check payable jointly to himself and his wife, and deposited the check in her bank account. The trustee was not allowed to recover the cash surrender value. 